\title{
Impacts of Tropical Forest Disturbance Upon Avifauna on a Small Island with High Endemism: Implications for Conservation
}

\author{
Thomas Edward Martin\# and George Alan Blackburn
}

Department of Geography, Lancaster University, Lancaster, Lancashire, UK

\#Corresponding author. E-mail: t.martin1@lancaster.ac.uk; blackbga@lancaster.ac.uk

\begin{abstract}
Tropical forests are rapidly being lost across Southeast Asia and this is predicted to have severe implications for many of the region's bird species. However, relationships between forest disturbance and avifaunal assemblages remain poorly understood, particularly on small island ecosystems such as those found in the biodiversity 'hotspot' of Wallacea. This study examines how avifaunal richness varies across a disturbance gradient in a forest reserve on Buton Island, southeast Sulawesi. Particular emphasis is placed upon examining responses in endemic and red-listed species with high conservation importance. Results indicate that overall avian richness increases between primary and 30-year-old regenerating secondary forest and then decreases through disturbed secondary forest, but is highest in cleared farmland. However, high species richness in farmland does not signify high species distinctiveness; bird community composition here differs significantly from that found in forest sites, and is poor in supporting forest specialists and endemic species. Certain large-bodied endemics such as the Knobbed Hornbill (Rhyticeros cassidix) appear to be sensitive to moderate disturbance, with populations occurring at greatest density within primary forest. However, overall endemic species richness, as well as that of endemic frugivores and insectivores, is similar in primary and secondary forest types. Results indicate that well-established secondary forest in particular has an important role in supporting species with high conservational importance, possessing community composition similar to that found in primary forest and supporting an equally high richness of endemic species.
\end{abstract}

Keywords: anthropogenic disturbance, bird communities, island endemics, tropical rainforest, Wallacea

DOI: $10.4103 / 0972-4923.68914$

\section{INTRODUCTION}

Southeast Asia's rainforests are facing the highest relative rates of habitat destruction of any major tropical area (Mayaux et al. 2005, Achard et al. 2002) and this has been identified as the major driving force of potential biodiversity loss across the region (Sodhi et al. 2004a). This has severe implication for the biodiversity 'hotspot' of Wallacea, a biogeographical region where a complex geological history has facilitated a high prevalence of endemic fauna (Whitten et al. 2002, Myers et al. 2000, Kinnaird 1995). Over $46 \%$ of resident vertebrates are restricted entirely to the hotspot, including more than 35\% of bird species (Myers et al. 2000), while Sulawesi, the region's largest island, supports 14 endemic bird genera, the highest of all globally identified endemic bird areas (Stattersfield et al. 1998). As with much of Indonesia, Wallacean forests are being subjected to heavy clearance, primarily from expanding agricultural activities related to population growth and socio-economic factors (Trainor 2007, Sodhi 2005a), but also from unsustainable logging practices (Marsden 1998). An estimated $55 \%$ of original vegetation cover and $85 \%$ of original pristine rainforest within the region has been lost or modified (Forest Watch Indonesia/Global Forest Watch 2002). Predictive extinction models estimate that continued habitat alterations on this scale could result in the loss of up to $42 \%$ of flora and fauna species across Southeast Asia by 2100 (Sodhi et al. 2004a), although consequences could be more severe still in the Wallacea region due to its insular nature, being comprised of 13,500 oceanic islands (Trainor 2007). Island birds have been estimated to possess extinction risks up to 40 times greater than continental species due to their small ranges and population sizes, and consequently are highly vulnerable to habitat destruction (Trevino et al. 2007, Pimm et al. 1995). Indeed, over $90 \%$ of recent (post AD

Copyright: (C) Martin and Blackburn 2010. This is an open access article distributed under the terms of the Creative Commons Attribution License, which permits unrestricted use and distribution of the article, provided the original work is cited. 
$1600)$ bird extinctions have been island endemics (Clements 2007, Birdlife International 2004), and almost $40 \%$ of species currently listed as threatened by the IUCN are restricted to oceanic islands- a highly disproportionate figure given the small land mass and contribution to global avian richness these ecosystems represent (IUCN 2009, Trevino et al. 2007, Johnson and Stattersfield 1990).

Safeguarding the unique biodiversity of this important region is therefore a high conservation priority, and extensive research is required to determine more precisely how habitat loss and change impacts upon biodiversity so that effective measures may be taken to mitigate these impacts. However, due to its isolation, current understanding of the ecological associations of avifaunal communities in this area remains poor. Aside from a few recent surveys (Coates and Bishop 1997, White and Bruce 1987), the most reliable accounts of bird communities on many Wallacean islands date back to collectors' reports from the late nineteenth century (Trainor 2007) while the bulk of current research has focussed on lowland areas or on larger islands (Lee et al. 2007, Sodhi et al. 2005b, Waltert et al. 2004, Thiollay et al. 2002). Few studies have examined bird communities on small island or montane ecosystems, which are often highly endemic and potentially more ecologically fragile (Macarthur and Wilson 1967). This paper seeks to address this by examining variations in avifaunal communities across a disturbance gradient on a small Wallacean island.

The study focuses on Buton, an attendant island of Sulawesi, which is representative of a small island ecosystem with a highly endemic avifauna assemblage. Recent work on these islands focussing on herpetofauna (Gillespie et al. 2005) and butterflies (Fermon et al. 2005) has demonstrated the complex nature of the relationships between forest disturbance and the distributions of endemic and habitat-specialist taxa. It has also highlighted the urgent need for more extensive research on the human impact on biodiversity in this region. The study also examines how a select key species, the Knobbed Hornbill Rhyticeros cassidix, responds to environmental disturbance. This species was chosen due to its potential as both a conservation flagship and an umbrella species (Sutherland 2000, Caro and O'Doherty 1999). It is a highly distinctive, charismatic bird which is widely recognised locally, being the faunal symbol of South Sulawesi province. Further, its function as an important seed disperser, coupled with its extensive habitat requirements (Kinnaird 1998), mean its conservation could have wider benefits for other organisms in its range. The relationship between environmental disturbance and the populations of several other large-bodied Sulawesi endemic species is also examined, as is the ecological response of forest specialist species, dietary guilds and regional endemic avifauna overall.

\section{MATERIALS AND METHODS}

\section{Study site}

The study focuses on Buton Island, the largest $\left(5,600 \mathrm{~km}^{2}\right)$ attendant island of Sulawesi in the Indonesian archipelago (Figure 1). The island is approximately $100 \mathrm{~km}$ long and 42 $\mathrm{km}$ wide at its widest point. Altitude ranges from $0-200 \mathrm{~m}$ in coastal areas to $400 \mathrm{~m}$ along the island's central spine, with

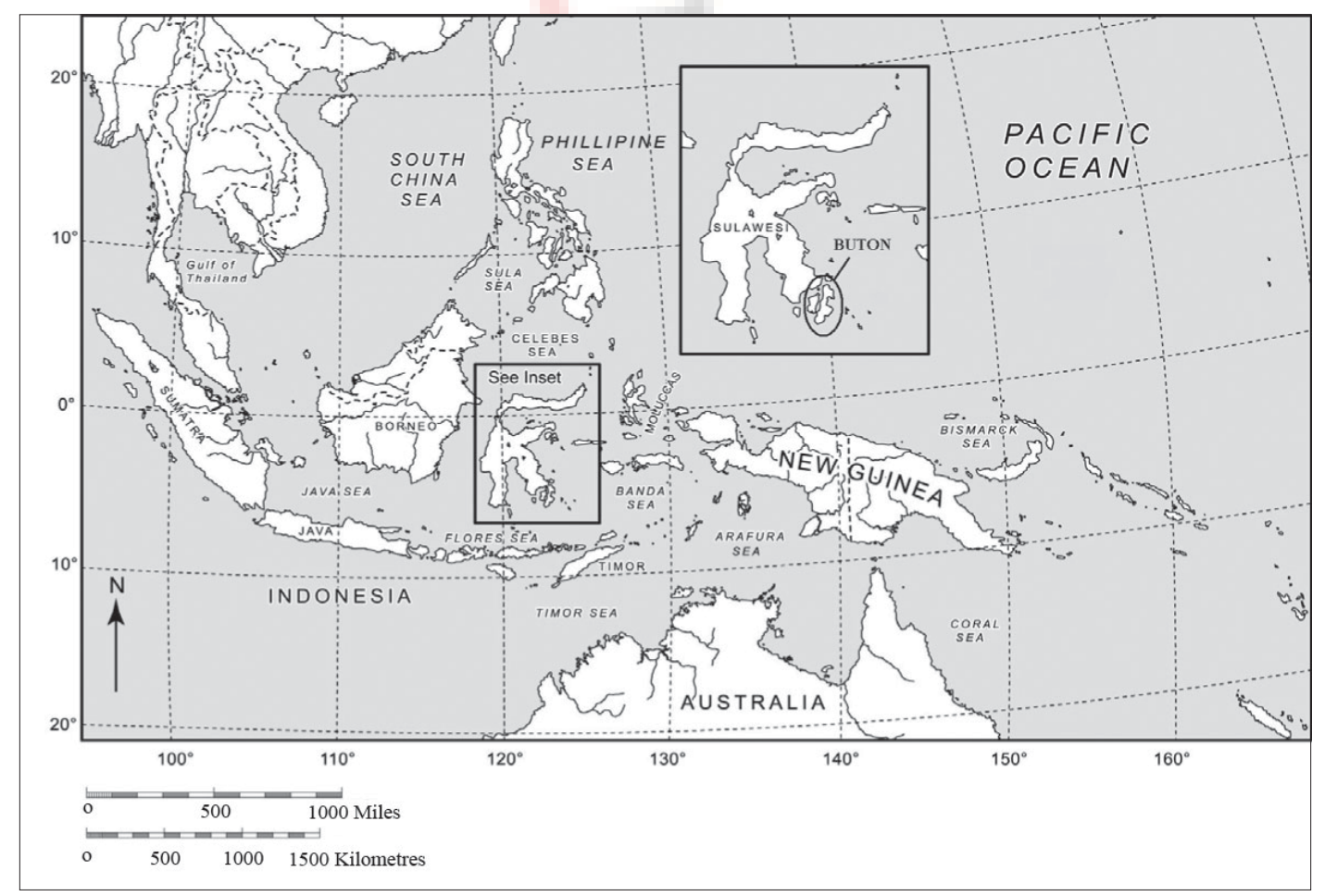

Figure 1

The Indonesian archipelago. Inset displays location of Sulawesi and Buton island 
isolated peaks reaching up to $1000 \mathrm{~m}$ (Whitten et al. 2002, O’Donovan 2001). Buton experiences a tropical monsoon climate with a June-September dry season and a NovemberApril wet season. Mean annual rainfall ranges between 1500-2000 mm, peaking between April and June (Whitten et al. 2002), with mean annual temperatures of $25-27^{\circ} \mathrm{C}$. Recent work using remotely-sensed and GIS data has identified much of the island as being of high conservation value (Cannon et al. 2007). Buton has been shown to support a rich avifauna, with at least 231 bird species including 52 Sulawesi endemics being reported (Catterall 1997). However, the island's forest habitats have undergone significant clearance in recent years. Between 1991-2002 over 13\% of land in Southern Buton (27,809 ha) was converted from forest to non-forest land use (Seymour 2004). The primary cause of this deforestation is considered to be agricultural expansion by small-holder farms, occurring due to both population increase and an influx of trans-migrant settlers from Bali and the Moluccas (Seymour 2004). Further clearance has resulted from selective logging and asphalt mining (Seymour 2004).

Research was conducted in and around the Lambusango Forest $\left(5^{\circ} 10^{\prime} \mathrm{S}, 122^{\circ} 24^{\prime} \mathrm{E}\right)$, a 65,000 hectare area of uninhabited lowland tropical forest divided into a 28,510 hectare strict forest reserve and a 35,000 hectare limited production forest (Singer and Purwanto 2006) (Figure 2). A great diversity of tree species occurs within the reserve, with no single family being predominant. The underlying geology of the area is Quaternary karst coral limestone (O’Donovan 2001).

\section{Sample sites}

Sampling was conducted in three forest areas located throughout the reserve. Analysis of habitat structure (see below), supported by visual observations and research into local ecological history, suggests that these three forest areas correspond approximately to areas of near-pristine primary forest in the limited production forest; well-regenerated secondary forest in the strict reserve that was subjected to agricultural clearance and logging until the Lambusango conservation area was set up in 1975, and heavily-disturbed secondary forest in the reserve's periphery which has been recently subjected to intermittent logging, shifting cultivation and rattan extraction. The underlying environmental parameters of these last two categories (geology, topography, etc) is expected be similar to the primary forest sites, with disturbance being the only significant cause of difference in vegetation structure. Each of these disturbance classes was far enough removed from other forest types to be considered independent. Additionally, an area of recently-cleared mixed farmland consisting of cassava (Manihot esculenta), papaya

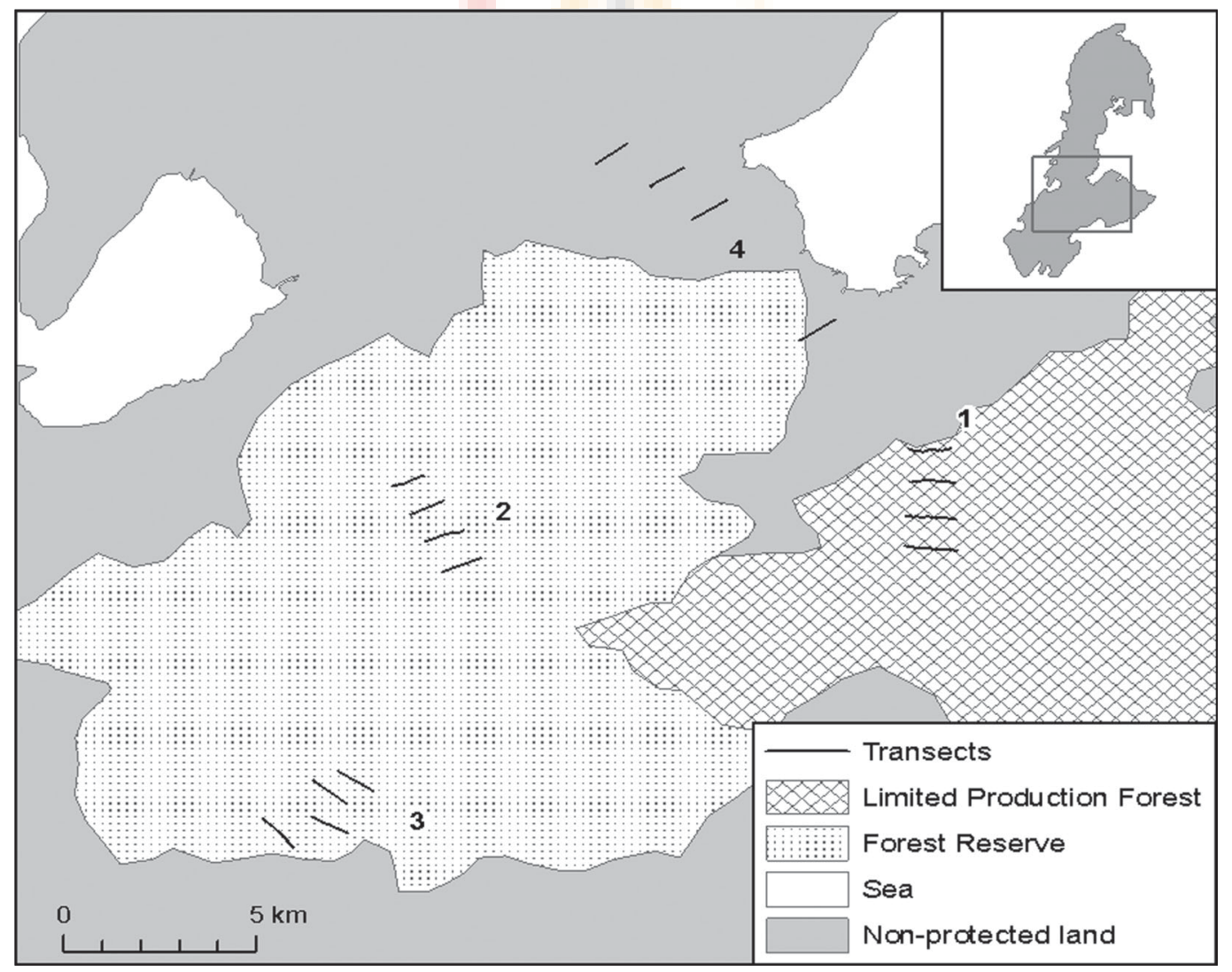

Figure 2

The Lambusango forest reserve and relative locations of study transects. Inset shows study area's location within Buton Island. Transects located within areas of primary forest, regenerating secondary forest, disturbed secondary forest and farmland are notated 1, 2, 3 and 4 respectively 
Table 1

Vegetation analysis summary for primary forest, regenerating secondary forest, disturbed secondary forest and cleared agricultural land within the Lambusango forest reserve, Buton Island, Southeast Sulawesi. \pm indicates variance to 1 standard deviation.

\begin{tabular}{|l|c|c|c|c|c|}
\hline & $\begin{array}{c}\text { Mean canopy } \\
\text { score }(0-25)\end{array}$ & $\begin{array}{c}\text { Mean frequency } \\
\text { of large trees } \\
(>50 \mathrm{~cm} \text { dbh) }\end{array}$ & $\begin{array}{c}\text { Mean dbh of large } \\
\text { trees }(\mathrm{cm})\end{array}$ & $\begin{array}{c}\text { Undergrowth } \\
\text { density }(\%)\end{array}$ & Rattan cover (\%) \\
\hline Primary forest & $4.02 \pm 1.27$ & $4.8 \pm 1.89$ & $83.9 \pm 35.2$ & $17.17 \pm 5.1$ & $21 \pm 14.1$ \\
\hline Regenerating secondary forest & $4.66 \pm 1.3$ & $2.1 \pm 0.9$ & $68.77 \pm 18.32$ & $24.4 \pm 0.7$ & $22.5 \pm 12.3$ \\
\hline Disturbed secondary forest & $6.36 \pm 1.73$ & $2.3 \pm 1.1$ & $61.763 \pm 15.2$ & $17.8 \pm 1.6$ & $52.1 \pm 27.5$ \\
\hline Farmland & $\mathrm{n} / \mathrm{a}$ & 0 & $\mathrm{n} / \mathrm{a}$ & 0 & 0 \\
\hline
\end{tabular}

(Carica papaya) and rice fields (Oryza sp.) was surveyed. Four $900 \mathrm{~m}$ linear transects spaced at least $1 \mathrm{~km}$ apart were used in each area (Figure 2). Linear transects were used as these presented the most logistically viable way of conducting surveys in the protected forest, as establishing scattered plots throughout the reserve would have required extensive trailcutting which would not have been possible given time and accessibility constraints, and could have been ecological damaging given access trails do not currently exist across much of the reserve. Each transect contained seven sample sites, with each site being spaced $150 \mathrm{~m}$ apart. This gave a total of 112 study sites with 28 sites located in each habitat category. The elevation of primary and disturbed secondary forest sites varied between 300-400 m, while elevation of the regenerating secondary forest sites varied between 650-700 $\mathrm{m}$. These altitudinal variations are not expected to be great enough to cause significant systematic changes in vegetation structure, being within the elevation range of lowland forest (Whitten et al. 2002). Farmland sites were located at elevations between 100-150 m.

\section{Vegetation sampling}

A series of vegetation variables were measured within a 20 $\mathrm{m}$ radius of each forest study site to provide evidence for differences in habitat structure. Vegetation variables were not measured in farmland sites, as differences in habitat structure here were clearly evident.

The sum total of large trees with a diameter at breast height (dbh) of $>50 \mathrm{~cm}$ was counted within each plot, with the mean $\mathrm{dbh}$ of large trees also being recorded at each site. Canopy cover was evaluated at each plot utilising a canopy scope constructed from a perspex square marked with a 5 X5 grid of dots separated by $3 \mathrm{~cm}$ (Brown et al. 2000). At each site five measurements were taken, with density assessed by holding the scope $10 \mathrm{~cm}$ away from an observer's eye-level and towards the largest visible canopy gap, with the number of dots unobscured by vegetation being recorded, thus a higher number reflects a more open canopy. Relative understorey densities were estimated utilising a $1.5 \mathrm{~m}$ measuring pole marked with 50 black bands. The pole was held horizontally $1 \mathrm{~m}$ off the ground, where a consistent observer counted the number of bands completely unobscured by vegetation at 10 $\mathrm{m}$ at four points within each quadrat. Again a higher number is indicative of a sparser understorey density. Coverage of rattan (Calamus sp.), which can be gauged as an indicator of forest quality due to its invasive nature in recently disturbed habitats, was also estimated visually as a percentage of the area of each plot (Table 1).

\section{Bird sampling}

Bird communities were surveyed at each study site using 50 $\mathrm{m}$ fixed-radius circular plot point counts (Bibby et al. 2002). Each point count was repeated once, with the total number of species detected after both counts being recorded. Point count surveys were led by the first author and Mr Dani Heryadi of Operation Wallacea, who both had several months' field experience with avifauna in the Lambusango, in addition to several years experience working with tropical birds. The data collection period corresponded to the breeding season for most local bird species.

Sampling was conducted each morning between 06:00 and 08:00, this being the period where bird detectibility is highest and mobility is low, reducing the chance of recording contacts multiple times (Marsden 1999, Wunderle 1994). Point count samples were begun on immediate arrival at each study site, with no 'settling in' period being used. This has been shown to allow the recording of any birds disturbed by the surveyors, thereby increasing the number of contacts made per count (Lee and Marsden 2008). A 10 minute sampling period was used, as counts of this length have a reduced likelihood of multiple contact recording, while still being capable of detecting $>80 \%$ of bird species present in an area (Lynch 1995, Waide and Wunderle 1987). All species seen and heard during each count were recorded, excluding those flying above the canopy, as these may have been wandering or passage birds not associated with the habitat being assessed. Point counts were not carried out in rain or heavy mist.

\section{Statistical analysis}

The mean number of species detected at sample sites after one repetition was calculated and compared for each habitat category using non-parametric Kruskal-Wallis one-way ANOVA and Mann-Whitney U-tests (Zar 1999). The mean number of Sulawesi endemic and forest specialist species per site (identified after Coates and Bishop 1997), were also compared using the same non-parametric analysis, as was the mean number of dedicated frugivorous and insectivorous 
species, as well as endemic frugivores and insectivores. These feeding guilds were chosen as they have been hypothesised to be particularly susceptible to habitat modification. Diversity of forest frugivores is often linked to the richness of fruiting plant species, which are most diverse in undisturbed forest ecosystems, and birds of this feeding guild often require large foraging areas due to the spatial and temporal scarcity of yearround fruit resources; thus degradation and fragmentation of forest ecosystems impacts strongly upon these species (Gray et al. 2009, Sodhi et al. 2004b). Insectivores have also been considered to be strongly affected by habitat modification due to their dependence on specific foraging microhabitats and possessing limited dispersal capabilities (Sodhi et al. 2004b). Feeding guilds were assigned following BirdLife International (2008), Coates and Bishop (1997), and White and Bruce (1987). All these comparisons were tested using a $95 \%$ confidence interval.

Sample-based rarefaction curves plotting numbers of individuals recorded against number of species detected were calculated utilising the software package EstimateS (Colwell 2006). A further three non-parametric species-richness estimators (ACE, Chao 2, and MMMeans) were calculated using 50 randomisation runs on the software package EstimateS (Colwell 2006). These estimators were chosen as they have been shown to be appropriate for extrapolating tropical bird community richness (Herzog et al. 2002). The mean value of the three estimators were taken as an estimation of species richness in each habitat class as the effectiveness of different estimators is expected to vary with different data sets (Walther and Moran 1998). This was included to corroborate the results of the accumulation curve, as information in larger samples may be lost when 'rarefied' to the size of the smallest sample in the analysis (Lee et al. 2007, Sodhi et al. 2005a).

Comparisons of community structure between habitat categories were examined by constructing similarity matrices using PC-ORD version 5.0 and comparing congruence using a series of Mantel tests. Significance of these tests was determined by a Monte-Carlo procedure utilising 999 permutations (McCune and Grace 2002).

Kruskal-Wallis one-way ANOVA analysis was also utilised to compare mean abundance of $R$. cassidix individuals per study site in each habitat category, along with two other selected large-bodied endemic species; the insectivorous Pied Cuckoo Shrike (Coracina bicolor), classifying as Near Threatened by the IUCN (2009), and the frugivorous Golden-mantled Racquet-tail Parrot (Prioniturus platurus).

\section{RESULTS}

A total of 67 species and 1701 individual birds were recorded in the point count surveys. Table 2 summarises species detected within each habitat category. Figure 3 demonstrates that mean species richness per study site increases significantly between the primary forest and regenerating secondary forest sites, rising from a mean of $7.2 \pm 1.2$ to $9.3 \pm 1.4$ species per site (Mann-Whitney $\mathrm{U}=1138, P \leq 0.01$ ). As anthropogenic disturbance levels increase further, however, richness decreases again, with a drop in mean species per site to $7.2 \pm 1.1$ in disturbed secondary forest. This is significantly lower than that of regenerating secondary forest (Mann-Whitney $U=1125$, $P \leq 0.01$ ), although not significantly different from primary forest (Mann-Whitney $\mathrm{U}=1553, P=0.93$ ). Species richness per site in cleared agricultural land drops to $6.3 \pm 1.0$; significantly less than all forest habitat classes $(P \leq 0.05)$. Figure 4 shows similar patterns occurring within feeding guilds. The mean number of frugivorous and insectivorous species per site is not significantly different between primary and disturbed secondary forest (Mann-Whitney $P \geq 0.05$ for both). Richness of both feeding guilds is slightly higher in regenerating secondary forest, although no significant differences occurs between this habitat and primary forest (Mann-Whitney $P \geq 0.05$ for

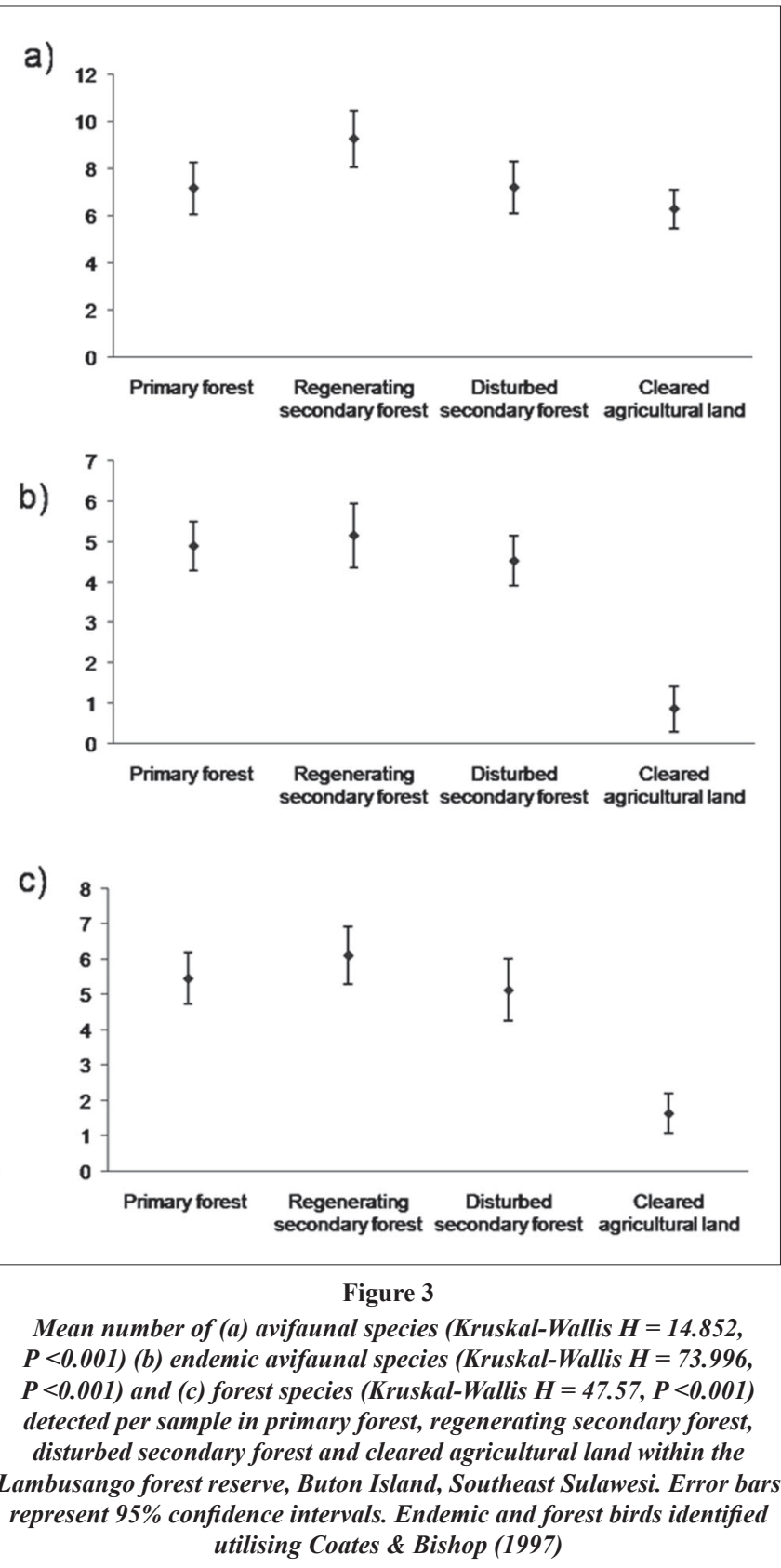


Table 2

Mean number of individuals per point count sample of each recorded species in primary forest, regenerating secondary forest, disturbed secondary forest and cleared agricultural land within the Lambusango forest reserve, Buton Island, Southeast Sulawesi. Bracketed figures show sample sized used to calculate means. Species ranked in taxonomical order after Wells (1998). Scientific and common names follow Coates \& Bishop (1997) Species in bold are endemic to the Sulawesi sub-region. Species marked $\dagger$ are classified as forest species after Coates \& Bishop (1997). Species marked (F) or (I) are classified as primarily frugivores or insectivores respectively, after BirdLife International (2008), Coates and Bishop (1997), and White and Bruce (1987). Species marked * have significantly different population densities across habitat types (Kruskal-Wallis $P<0.05)$.

\begin{tabular}{|c|c|c|c|c|c|}
\hline Scientific name & English name & Primary & Reg. Sec & Dist. Sec & Farm \\
\hline Ardea purpurea & Purple Heron & $0(0)$ & $0(0)$ & $0(0)$ & $0.04(2)$ \\
\hline Egretta alba & Great Egret & $0(0)$ & $0(0)$ & $0(0)$ & $0.04(2)$ \\
\hline Egretta garzetta* & Little Heron & $0(0)$ & $0(0)$ & $0(0)$ & $0.07(4)$ \\
\hline Haliastur indus & Brahminy Kite & $0(0)$ & $0.04(2)$ & $0(0)$ & $0(0)$ \\
\hline Spilornis rufipectus $\dagger$ & Sulawesi Serpent Eagle & $0.04(2)$ & $0.04(2)$ & $0.04(2)$ & $0(0)$ \\
\hline Accipiter trinotatus $\dagger^{*}$ & Spot-tailed Goshawk & $0.13(7)$ & $0.14(8)$ & $0.02(1)$ & $0.82(0)$ \\
\hline Ictinaetus malayensis $\dagger$ & Black Eagle & $0(0)$ & $0(0)$ & $0(0)$ & $0.04(3)$ \\
\hline Dendrocygna arcuata & Wandering Whistling Duck & $0(0)$ & $0(0)$ & $0(0)$ & $0.04(2)$ \\
\hline Gallus gallus $\dagger$ (I) & Red Junglefowl & $0(0)$ & $0.05(3)$ & $0.04(3)$ & $0(0)$ \\
\hline Amaurornis isabellina & Isabelline Waterhen & $0(0)$ & $0(0)$ & $0(0)$ & $0.02(1)$ \\
\hline Ducula aenea $(\mathrm{F})^{*}$ & Green Imperial Pigeon & $0.21(12)$ & $0.55(31)$ & $0.29(16)$ & $0.25(14)$ \\
\hline Ducula forsteni ${ }^{\dagger}(\mathrm{F})^{*}$ & White-bellied Imperial Pigeon & $0.09(5)$ & $0.2(11)$ & $0(0)$ & $0(0)$ \\
\hline Ducula luctaosa $(\mathrm{F})$ & Silver-tipped Imperial Pigeon & $\mathbf{0}(\mathbf{0})$ & $0.04(2)$ & $\mathbf{0}(\mathbf{0})$ & $0.02(1)$ \\
\hline Macropygia amboinensis $(\mathrm{F})$ & Brown Cuckoo-dove & $0(0)$ & $0.04(2)$ & $0.02(1)$ & $0(0)$ \\
\hline Treron griseicauda $(\mathrm{F})$ & Grey-cheeked Green Pigeon & $0(0)$ & $0(0)$ & $0.02(1)$ & $0(0)$ \\
\hline Ptilinopus melanospila $(\mathrm{F})^{*}$ & Black-naped Fruit-dove & $0.11(6)$ & $0.23(13)$ & $0.23(12)$ & $0.02(1)$ \\
\hline Streptopelia chinensis* & Spotted Dove & $0(0)$ & $0(0)$ & $0(0)$ & $0.46(26)$ \\
\hline Turacoena manadensis $(\mathrm{F})$ & Sulawesi Black Pigeon & $0.02(1)$ & $0.02(1)$ & $0.07(4)$ & O (0) \\
\hline Trichoglossus ornatus (F) & Ornate Lorikeet & $0(0)$ & $0(0)$ & $0.08(4)$ & $0(0)$ \\
\hline Prioniturus platurus $\dagger(\mathrm{F})^{*}$ & Golden-mantled Racquet-tail & $1.3(73)$ & $0.34(19)$ & $0.09(5)$ & $0(0)$ \\
\hline Tanygnathus sumatranus $(\mathrm{F})$ & Blue-backed Parrot & $0.02(1)$ & $0.05(3)$ & $0.02(1)$ & $0.02(1)$ \\
\hline Loriculus stigmatus† $(\mathbf{F})$ & Sulawesi Hanging Parrot & $0.09(5)$ & $0.04(2)$ & $0.16(9)$ & $0(0)$ \\
\hline Cacomantis merulinus (I) & Plaintive Cuckoo & $0(0)$ & $0(0)$ & $0(0)$ & $0.02(1)$ \\
\hline Surniculus lugubris $\uparrow$ (I) & Drongo-cuckoo & $0(0)$ & $0.04(2)$ & $0.05(3)$ & $0.04(2)$ \\
\hline Phaenicophaetus calyorhynchus (I) & Yellow-billed Malkoa & O (0) & $0(0)$ & $0.04(2)$ & $0.05(3)$ \\
\hline Centropus bengalensis (I) & Lesser Coucal & $0(0)$ & $0(0)$ & $0(0)$ & $0.30(17)$ \\
\hline Centropus Celebensis† (I)* & Bay Coucal & $0.29(16)$ & $0.38(21)$ & $0.30(17)$ & O (0) \\
\hline Collocalia esculenta (I) & Glossy Swiftlet & $0(0)$ & $0(0)$ & $0(0)$ & $0.04(2)$ \\
\hline Hemiprocne longipennis (I) & Grey-rumped Tree-swift & $0(0)$ & $0(0)$ & $0.05(3)$ & $0.07(4)$ \\
\hline Halcyon coromanda & Ruddy Kingfisher & $0(0)$ & $0(0)$ & $0(0)$ & $0.02(1)$ \\
\hline Halcyon chloris* & Collared Kingfisher & $0.02(1)$ & $0(0)$ & $0(0)$ & $0.4(23)$ \\
\hline Penelopides exhartus $\dagger(\mathrm{F})^{*}$ & Sulawesi Dwarf Hornbill & $0.11(6)$ & $0.25(14)$ & $0.2(11)$ & $0(0)$ \\
\hline Rhyticeros cassidix $\dagger(\mathbf{F})^{*}$ & Knobbed Hornbill & $0.23(13)$ & $0.2(11)$ & $0.04(2)$ & $0.04(2)$ \\
\hline Mulleripicus fulvus $\dagger(\mathrm{I})^{*}$ & Ashy Woodpecker & $0.29(15)$ & $0.14(8)$ & $0.07(4)$ & $0(0)$ \\
\hline Pitta erythrogaster† (I) & Blue-breasted Pitta & $0(0)$ & $0.04(2)$ & $0.05(3)$ & $0(0)$ \\
\hline Hirundo tahitica $(\mathrm{I})^{*}$ & Pacific Swallow & $0(0)$ & $0(0)$ & $0(0)$ & $0.09(5)$ \\
\hline Coracina bicolor $\dagger(\mathrm{I}) *$ & Pied Cuckoo-shrike & $0.39(22)$ & $0.68(38)$ & $0.14(8)$ & $0(0)$ \\
\hline Coracina leucopygia (I) & White-rumped Cuckoo-shrike & $0.13(7)$ & O (0) & $0(0)$ & $0(0)$ \\
\hline Coracina morio $\dagger(\mathrm{I})^{*}$ & Sulawesi Cicadabird & $0.29(16)$ & 0.29 (16) & $0.23(13)$ & $0.02(1)$ \\
\hline Dicrurus hottentotus (I) & Hair-crested Drongo & $0.5(28)$ & $0.88(49)$ & $0.55(31)$ & $0.39(25)$ \\
\hline Oriolus chinensis $\dagger(\mathrm{F})$ & Black-naped Oriole & $0.41(23)$ & $0.43(24)$ & $0.39(22)$ & $0.34(19)$ \\
\hline Corvus enca & Slender-billed Crow & $0(0)$ & $0(0)$ & $0.04(2)$ & $0.05(3)$ \\
\hline Corvus typicus $\dagger^{*}$ & Piping Crow & $0.05(3)$ & $0.2(11)$ & $0(0)$ & $0(0)$ \\
\hline Trichastoma celebense (I) & Sulawesi Babbler & $0.64(36)$ & $0.68(40)$ & $0.98(55)$ & $0.82(44)$ \\
\hline Gerygone sulphurea (I)* & Flyeater & $0(0)$ & $0(0)$ & $0(0)$ & $0.09(5)$ \\
\hline Culicicapa helianthea (I)* & Citrine Flycatcher & $0.25(14)$ & $0.27(15)$ & $0.36(20)$ & $0.02(1)$ \\
\hline Hypothymis azurea (I) & Black-naped Monarch & $0.43(24)$ & $0.55(31)$ & $0.57(32)$ & $0.57(32)$ \\
\hline Artamus leucorhynchus (I)* & White-breasted Wood-swallow & $0(0)$ & $0(0)$ & $0(0)$ & $0.36(20)$ \\
\hline Aplonis panayensis & Asian Glossy Starling & $0(0)$ & $0.27(15)$ & $0(0)$ & $0.30(17)$ \\
\hline Scissirostrum dubium $(\mathrm{F})$ & Grosbeak Starling & $0.01(1)$ & $\mathbf{0}(\mathbf{0})$ & $0.38(21)$ & $0(0)$ \\
\hline Basilornis celebensis $\dagger(\mathrm{F})$ & Sulawesi Crested Myna & $0.02(1)$ & $0.02(1)$ & $\mathbf{0}(0)$ & $\mathbf{0}(\mathbf{0})$ \\
\hline Streptocitta albicollis $\dagger(\mathrm{F})$ & White-necked Myna & $0.13(7)$ & $0.05(3)$ & $0.13(7)$ & $0.02(1)$ \\
\hline
\end{tabular}


Table 2 (Contd....)

\begin{tabular}{|c|c|c|c|c|c|}
\hline Scientific name & English name & Primary & Reg. Sec & Dist. Sec & Farm \\
\hline Myzomela sanguinolenta $(\mathrm{F})$ & Scarlet Honeyeater & $0(0)$ & $0(0)$ & $0(0)$ & $0.04(2)$ \\
\hline Anthreptes malacensis $(\mathrm{F})$ & Brown-throated Sunbird & $0(0)$ & $0(0)$ & $0(0)$ & $0.05(3)$ \\
\hline Nectarina Aspasia $(\mathrm{F}) *$ & Black Sunbird & $0.86(47)$ & $1.11(61)$ & $0.45(25)$ & $0.23(13)$ \\
\hline Nectarina jugularis $(\mathrm{F})$ & Olive-backed Sunbird & $0(0)$ & $0.05(3)$ & $0.02(1)$ & $0.07(4)$ \\
\hline Aethopyga siparaja $(\mathrm{F})^{*}$ & Crimson Sunbird & $0(0)$ & $0(0)$ & $0(0)$ & $0.07(4)$ \\
\hline Dicaeum aureolimbatum $\dagger(\mathrm{F})$ & Yellow-sided Flowerpecker & $0.02(1)$ & $0.07(4)$ & $0.09(5)$ & $0.05(3)$ \\
\hline Dicaeum celebicum† $(\mathrm{F})$ & Grey-sided Flowerpecker & $0(0)$ & $0.02(1)$ & 0.07 (4) & $0.04(2)$ \\
\hline Zosterops celebense $(\mathrm{F}) *$ & Sulawesi White-eye & $0.25(14)$ & $0.39(22)$ & $0.34(19)$ & O (0) \\
\hline Zosterops consobrinorum $(\mathrm{F})^{*}$ & Lemon-bellied White-eye & $0(0)$ & $0(0)$ & $0.05(3)$ & $0.55(31)$ \\
\hline Passer montanus* & Tree Sparrow & $0(0)$ & $0(0)$ & $0(0)$ & $0.39(22)$ \\
\hline Lonchura molucca* & Black-faced Muniah & $0(0)$ & $0(0)$ & $0(0)$ & $0.05(3)$ \\
\hline Lonchura punctulata* & Scaly-breasted Muniah & $0(0)$ & $0(0)$ & $0(0)$ & $1.2(56)$ \\
\hline Lonchura malacca* & Chestnut Muniah & $0(0)$ & $0(0)$ & $0(0)$ & $0.13(7)$ \\
\hline
\end{tabular}

a)

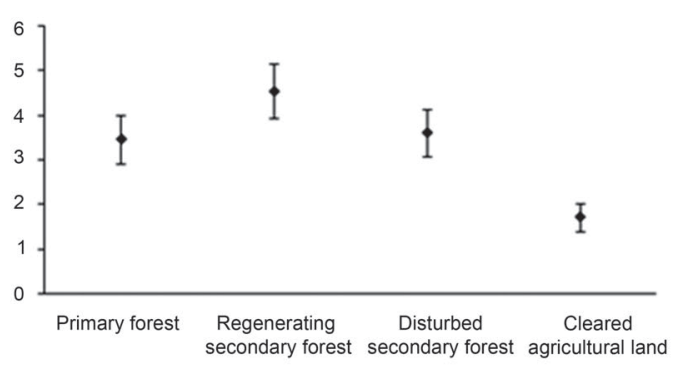

b)

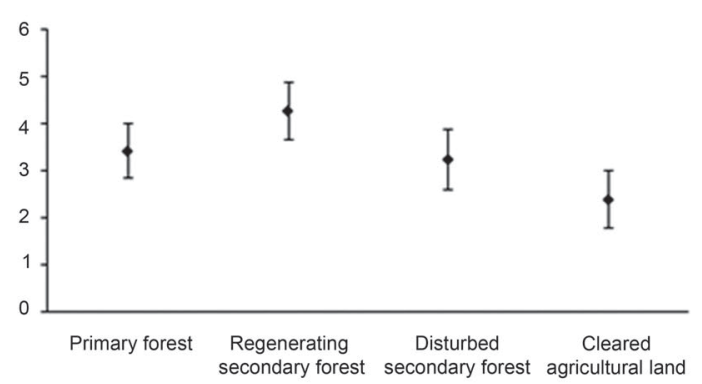

c)

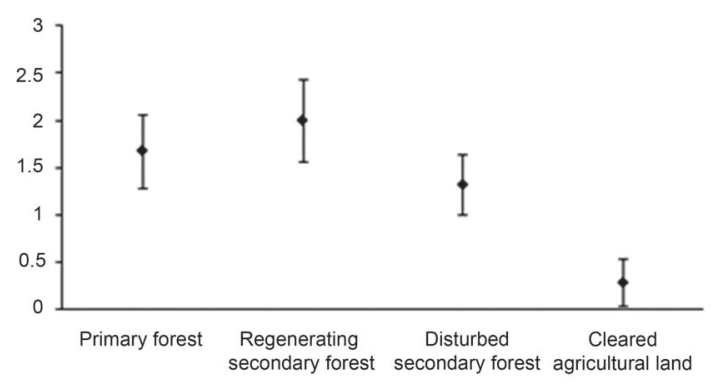

d)

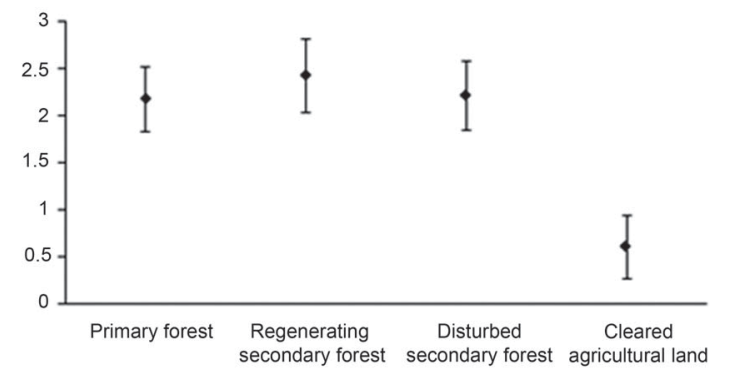

Figure 4

Mean number of (a) frugivorous species (Kruskal-Wallis $H=26.68, P<0.001$ ) (b) insectivorous species (Kruskal-Wallis $H=22.3, P<0.001$ ) (c) endemic frugivores (Kruskal-Wallis $H=29.41, P<0.001$ ) and (d) endemic insectivores (Kruskal-Wallis $H=42.73, P<0.001$ ) detected per sample in primary forest, regenerating secondary forest, disturbed secondary forest and cleared agricultural land within the Lambusango forest reserve, Buton Island, Southeast Sulawesi. Error bars represent 95\% confidence intervals. Feeding guilds assigned after BirdLife International (2008), Coates and Bishop (1997), and White and Bruce (1987).

both guilds). Cleared farmland has significantly less species of both feeding guilds per site compared to all forest habitats (Mann-Whitney $P \leq 0.01$ for all tests).

While mean aggregations of species per site suggest a relatively impoverished avifaunal assemblage in cleared farmland, other statistical analyses provide an alternative view. Average species richness estimates displayed in Table 3 were calculated as 31.8 (95\% confidence interval) for primary forest, 37.3 for regenerating secondary forest, 39.4 for disturbed secondary forest and 54.2 for farmland. This would suggest a trend towards increasing species richness with anthropogenic disturbance. Rarefaction curves in Figure 5 support this, predicting primary forest to have the most impoverished avifauna, with farmland having the highest number of species and species density. Regenerating secondary forest displays similar predicted overall species richness to disturbed secondary forest, which again implies that no simple direct correlation exists between avian richness and level of disturbance.

Mantel test r-values shown in Table 4 indicate that, although R-values are low, significant congruence occurs between bird community structure in primary forest and regenerating secondary forest $(r=0.154)$. Community structure in regenerating secondary forest and disturbed secondary forest also displayed significant similarity $(r=0.161)$. Community 
Table 3

Non-parametric species estimators for primary forest, regenerating secondary forest, disturbed secondary forest and cleared agricultural land within the Lambusango forest reserve, Buton Island, Southeast Sulawesi. $n$ represents sample size. Sp obs and Ind obs represent total number of species and individuals observed, respectively. ACE, CHAO2, and MMMeans are non-parametric species estimators (Colwell and Coddington 1994)

\begin{tabular}{|l|c|c|c|c|}
\hline \multicolumn{1}{|c|}{ Parameters } & Primary Forest & $\begin{array}{c}\text { Regenerating secondary } \\
\text { forest }\end{array}$ & $\begin{array}{c}\text { Disturbed secondary } \\
\text { forest }\end{array}$ & Farm \\
\hline $\mathrm{n}$ & 28 & 28 & 28 & 28 \\
\hline Sp obs & 29 & 35 & 35 & 46 \\
\hline Ind obs & 417 & 472 & 359 & 452 \\
\hline ACE & 31.83 & 37.21 & 39.68 & 51.71 \\
\hline Chao2 & 32.68 & 37.45 & 40.05 & 55.37 \\
\hline MMMeans & 30.99 & 37.33 & 38.35 & 55.51 \\
\hline Average species estimate & 31.8 & 37.3 & 39.4 & 54.2 \\
\hline
\end{tabular}

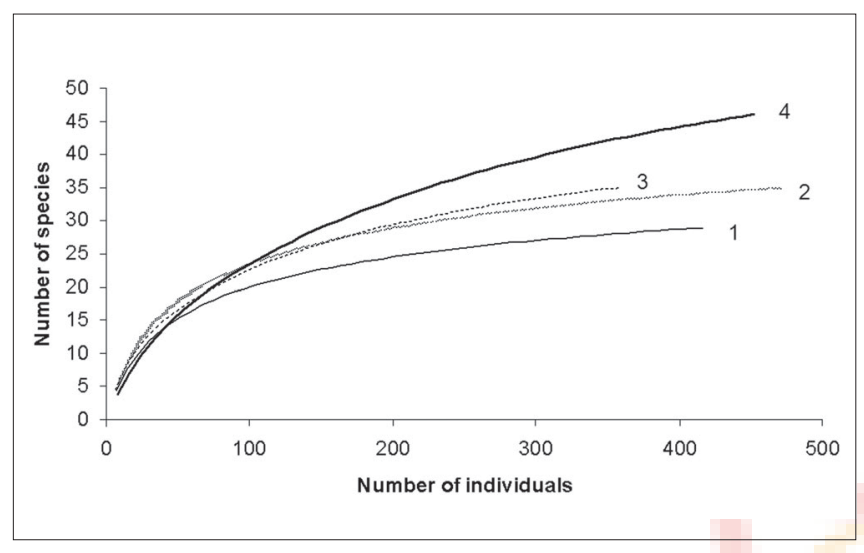

Figure 5

Sample-based rarefaction curves displaying number of individuals against number of species recorded in primary forest (notated as 1), regenerating secondary forest (notated at 2), disturbed secondary forest (notated as 3) and cleared agricultural land (notated as 4) sample sites within the Lambusango forest reserve, Buton Island, Southeast Sulawesi

structure in farmland sites was not significantly correlated with community structure in any forest sites.

Mean species per sample analysis in Figure 3 also demonstrates that richness of endemic species increases slightly between primary forest $(4.89 \pm 1.68$ species per sample site) and regenerating secondary forest $(5.14 \pm 1.69$ species per sample site), although this is not significant (Mann-Whitney $\mathrm{U}=1390$, $P=0.29$ ). Disturbed secondary forest also has a similar mean number of endemic species per sample site to primary forest (4.52 \pm 1.62 , Mann-Whitney $\mathrm{U}=1485, P=0.62)$. Just $0.86 \pm$ 0.42 endemic species per sample site were detected in cleared farmland, significantly less (Mann-Whitney $P \leq 0.01$ ) than all forest habitats. Forest species and endemic frugivores and insectivores (Figure 4) show a similar pattern of response. No significant difference in the number of species per site occurs between forest habitats in each of these categories (Mann-Whitney $P \geq 0.05$ for all comparisons), although cleared farmland had significantly less species per site than all forest classes (Mann-Whitney $P \leq 0.01$ for all comparisons).

Figure 6 demonstrates that abundance of $R$. cassidix decreases rapidly with increasing disturbance, falling from a mean abundance of 0.57 individuals per sample in primary forest to 0.39 individuals per sample in regenerating secondary forest, and
Table 4

Mantel test r-values comparing community similarity of bird assemblages between Primary forest, regenerating secondary forest, disturbed secondary forest and cleared farmland in the Lambusango forest reserve Buton Island, Southeast Sulawesi. Bold figures indicate statistically significant correlations. * indicates significance at a $95 \%$ confidence interval. ** indicates significance to a $99 \%$ confidence interval.

\begin{tabular}{|l|c|c|c|}
\hline & $\begin{array}{c}\text { Regenerating } \\
\text { secondary } \\
\text { forest }\end{array}$ & $\begin{array}{c}\text { Disturbed } \\
\text { secondary } \\
\text { forest }\end{array}$ & Farmland \\
\hline Primary forest & $0.154^{* *}$ & 0.07 & 0.065 \\
\hline $\begin{array}{l}\text { Regenerating } \\
\text { secondary forest }\end{array}$ & $\mathrm{X}$ & $0.161^{*}$ & 0.012 \\
\hline $\begin{array}{l}\text { Disturbed secondary } \\
\text { forest }\end{array}$ & $\mathrm{X}$ & $\mathrm{X}$ & 0.001 \\
\hline
\end{tabular}

levelling off at a value of virtual absence in disturbed secondary forest and farmland. The decline of $R$. cassidix across the four habitat categories shares a strong positive correlation with the number of large trees per plot at each site $\left(r^{2}=0.87\right)$. Similar trends of decline are also found in other selected large-bodied Sulawesi endemics; P. platurus and C. bicolor.

\section{DISCUSSION}

While mean species richness per sample demonstrates a general pattern of decline with increasing environmental disturbance, this is not a simple progressive relationship as has been found in other studies (Sodhi et al. 2005a, Thiollay et al. 2002), as richness rises significantly between primary and regenerated secondary forest before declining in the more disturbed sites. The rise in species richness between primary and regenerated secondary forest could perhaps be explained by the ecological history of the latter. These sites have been subjected to heavy disturbance in the past, but subsequently left undisturbed for over 25 years. Past disturbance would have led to major disruption of ecological niches, and while it is likely that a decline in the total diversity of avifaunal assemblages would have occurred due to local deterministic loss of specialist rainforest species (Pullin 2002), previous studies have shown that smaller numbers of generalist species are often able to colonise new niches created by disturbance that did not previously exist in the area (Sodhi et al. 2005a). 


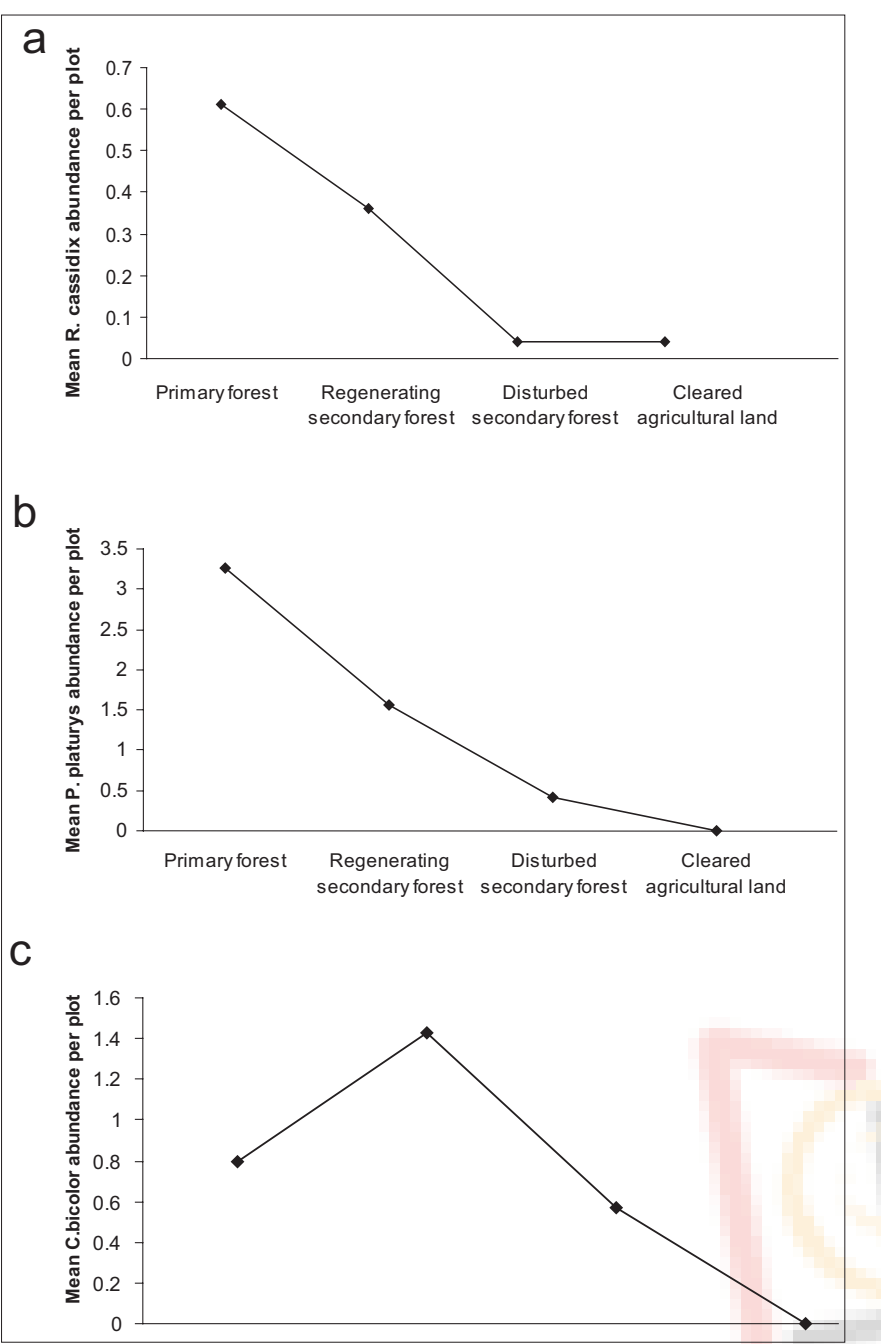

Figure 6

Mean abundance of select Sulawesi endemic species detected per plot in primary forest, regenerating secondary forest, disturbed secondary forest and cleared agricultural land within the Lambusango forest reserve, Buton Island, Southeast Sulawesi. (a) Rhyticeros cassidix (Kruskal-Wallis $\boldsymbol{H}=\mathbf{2 0 . 2 3 1 , P}<\mathbf{0 . 0 0 1}$, (b) Prioniturus platurus (Kruskal-Wallis $\boldsymbol{H}=39.538, P<0.001$, (c) Corcacina bicolor (Kruskal-Wallis $\boldsymbol{H}=28.092, \boldsymbol{P}<0.001$ ).

Over time and with regeneration of the forest, niches may again have appeared which accommodate forest specialists, but it is possible that certain generalist species have become established and remain; hence the higher species richness. This relates to the Theory of Intermediate Disturbance (Connell 1978), and may explain why total richness is significantly higher in regenerating secondary forest, but richness of endemics and forest species is not.

Species richness in disturbed secondary forest is somewhat higher than could be expected from findings of previous studies (Sodhi et al. 2005a), being statistically similar to that of primary forest. This, again, could possibly occur because of an overlap of opportunistic, generalist species with specialist forest species returning to the forest as it regenerates, as hypothesised for the regenerated secondary forest. However, the vegetation survey indicates that the disturbed secondary forest has not recovered so extensively, so it could be that fewer niches have become re-available for forest species, thus accounting for differences in richness between the two types of secondary forests.

Although overall richness varies across study sites, both secondary forest classes have a similar number of endemic species per site to primary forest, including frugivorous and insectivorous species. These findings would appear to support the conclusions of Veddeler et al. (2005) who, in their work on butterflies in central Sulawesi, recognised the significance of secondary forests, especially in older successional stages, in the conservation of tropical biodiversity. The conservation value of regenerating forest has also been demonstrated elsewhere in Indonesia, such as the Harapan Forest in Sumatra (BirdLife International 2008).

The results indicating a low mean number of species per sample in the farmland result from habitat structure. The farmland sites were largely cleared land with no significant tree growth, canopy or understorey, thus representing a heavily modified ecosystem to which forest species have not adapted, therefore creating deterministic extinctions as described by Sutherland (2000) and Pullin (2002). Further, it could be argued that as the farmland consists largely of monoculture crops, plant diversity in any given area would be comparatively low in relation to the mosaic of microhabitats represented in any pristine forest ecosystem. This lack of niches would limit the number of generalist species that could exploit the habitat change, and hence species richness is low. These results are in concordance with the findings of Sodhi et al. (2005a), who recorded mean avifaunal species numbers in farmed plantations as $15.67 \pm 1.07$ in contrast to a mean species richness of $31.99 \pm 1.38$ in primary forest, and of Trainor (2007), who reported comparable results. However, species estimates obtained from the non-parametric tests and the rarefaction curves predict cleared farmland to contain the highest total number of species, and primary forest the lowest. This could result from the heterogeneous nature of the cleared farmland. While the mean number of species per sampling point was low in the farmland, the high species richness predicted to occur across the entire agricultural area could result from the high spatial variability in vegetation and land-use; this would create a broad range of habitat niches on a larger spatial scale which in turn could support a more diverse avifauna than the more spatially contiguous primary forest. The high number of species predicted in the cleared farmland could also be a function of its proximity to more intact forest environments; this could result in forest specialists not typically found in agricultural land occurring as foragers based in roosts in adjacent forest habitats. Despite this proximity, the cleared farmland has a very low richness of endemics and forest species. This is in concordance with the findings of Peh et al. (2005), where only $28-32 \%$ of birds found in primary forest were also found in mixed-rural habitats, with estimates of species richness in agricultural land being even lower. These findings support the arguments noted by Fermon et al. (2005) - that higher overall species 
richness does not imply higher species distinctiveness, and that the contribution of land-use systems to global biodiversity should be evaluated with caution, even when high species richness estimates are found. This is further demonstrated by the mantel cross-similarity community comparisons, which indicate that no significant similarity exists between the compositions of farmland and forest bird assemblages. Species summaries show that community structures in these farmland sites are dominated by wide-ranging generalist species, including representatives from several families that were completely absent in forest habitats (i.e. Ardeiidae, Rallidae, Hirundinidae). This persistence of generalist species in these habitats over specialist insectivores and frugivores is concurrent with the findings of Sodhi et al. (2005a), while the apparent high vulnerability of regional endemics to heavy disturbance is concomitant with studies by Trainor (2007) and Posa and Sodhi (2006). Indeed, our results would appear to suggest that the specialisation of many of these endemic species is extremely fine, as in the areas of heavy disturbance certain endemic species are replaced by very similar generalist species which fulfil a comparable ecological role. Examples of this effect can be seen in population comparisons of endemics and widespread generalist species in the same genus: the Bay Coucal (Centropus celebensis) and Lesser Coucal (Centropus bengalensis), and the Sulawesi Whiteeye (Zosterops celebense) with the Lemon-bellied Whiteeye (Zosterops consobrinorum) (Figure 7). These results are in accordance with those for the abundance of endemics overall, which suggest that while many endemic species are abundant in both primary and secondary forests, they are virtually absent from the areas of heaviest disturbance, being replaced by generalist species not found in naturally vegetated areas. This further demonstrates the vulnerability to heavy anthropogenic disturbance of Buton's endemic avifauna and highlights the critical differences between the effects of intermittent logging and shifting cultivation which permit the regeneration of secondary forest and clearance for agriculture which largely eliminates the forest habitat.

Results indicating $R$. cassidix as highly vulnerable to even moderate environmental disturbance conflict with findings in certain other studies. Sodhi et al. (2005a), for example, found that high numbers of the species could be found even in degraded mixed-rural habitats, and Cahill (2003), while acknowledging the reliance of hornbill populations on large trees, describes $R$. cassidix as being fairly catholic in habitat preference. However, the negative correlation between frequency of large trees and $R$. cassidix abundance found in this study is very strong, and similar trends, at least in cleared farmland, have been found in the population dynamics of similar species such as Blyth's Hornbill (Rhyticeros plicatus) and Rhinoceros Hornbill (Buceros rhinoceros) (Marsden and Pilgrim 2003, Anggraini et al. 2001). Similar patterns of decline have also been found in other large-bodied Sulawesi endemics.

Strong negative relationships between abundance of largebodied forest birds and increasing disturbance have been

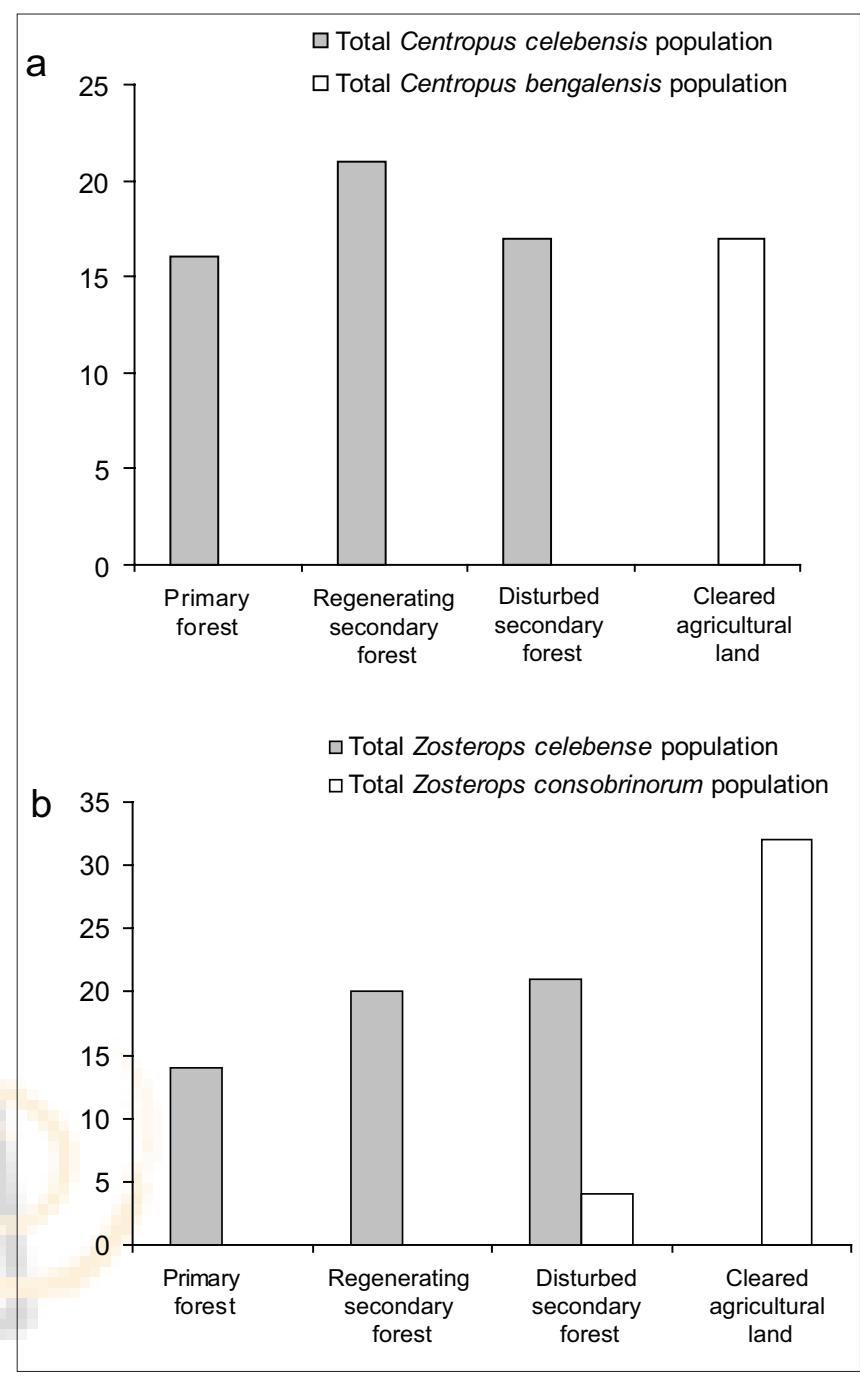

Figure 7

Mean abundance per plot of: a) Coucal species Centropus celebensis and Centropus bengalensis, and b) White-eye species Zosterops consobrinorum and Zosterops chloris in primary forest, regenerating secondary forest, disturbed secondary forest and cleared agricultural land within the Lambusango forest reserve, Buton Island, Southeast Sulawesi

reported and discussed in numerous other studies. Suggestions for the apparent extirpation vulnerability of these species include occurrence at naturally low densities, large habitat patch requirements, low reproductive rates and increased vulnerability to hunting (Boyer 2008, Sodhi et al. 2004a, Gaston and Blackburn 1995). In the case of R. cassidix, a likely explanation may relate to deterministic extinction processes. Cahill (2003), Anggraini et al. (2000) and Coates and Bishop (1997) describe how hornbill species are dependent on large, mature fruit-bearing trees to provide perennial feeding grounds and roosts, thus as habitat disturbance reduces the availability of these large trees, so the abundance of $R$. cassidix declines correspondingly. Findings here accord with those from previous work in Central Sulawesi that has demonstrated the importance of trees in structuring tropical forest habitats and in providing resources (Kessler et al. 2005). 


\section{CONCLUSION}

This study has demonstrated that the response of avifaunal assemblages to anthropogenic disturbance in the Lambusango reserve is subject to considerable complexity. Overall, avian species richness per study site increases between primary and secondary forest and then decreases through disturbed secondary forest to a level comparable with primary forest. Such variations may be attributable to ecological history and the relative abundances of endemics and generalists throughout the phases of initial forest disturbance, establishment and maturation of secondary forest. Further work is needed to examine such dynamics in greater detail and this will benefit from the ongoing long-term monitoring programme in Buton.

This research suggests that forest species and many specialist endemic species with a high conservation priority are highly intolerant of heavy disturbance, although many species persist in moderately disturbed forest ecosystems. Such responses have also been reported in other locations in Central Sulawesi (Sodhi et al. 2005, Thiollay and Rahman 2002) as well as for species in other taxonomical groups within Wallacea; notably Herpetofauna (Gillespie et al. 2005). This suggests that secondary forest ecosystems can have an important role in supporting endemics as well as overall avian diversity, although disturbed secondary forest is shown to be ineffective in conserving some of the region's larger-bodied endemic species with lower ecological tolerance. Secondary forest in later successional stages is indicated to have a particularly high conservational value, possessing a community structure similar to that found in primary forest and supporting an equally high numbers of endemics, insectivores, and frugivores as well as sizable populations of the large-bodied species evaluated. This is encouraging, given the large areas of disturbed forest ecosystems remaining on Sulawesi (Cannon et al. 2007), and that studies in other continental tropical ecosystems often indicate these habitats as being depauperate in endemics and forest specialists (Peh et al. 2008, Barlow et al. 2007, Burgess et al. 2002, Fjeldsa 1999, Canaday 1996). These findings therefore suggest the importance of allowing adequate regeneration of disturbed areas, a conservation priority also advocated by BirdLife International's habitat restoration initiatives in Sumatra (BirdLife International 2008). However, further work is needed to determine the extent to which populations within the secondary forest are dependent upon continual recruitment from adjacent primary forest refugia, and whether critical proportions of primary and secondary forests are needed for sustainability at the landscape scale. Hence, given the biological vulnerability of islands such as Buton, which are small in size and separated from the larger land masses, strong protection of the regions remaining primary forest should also be a focus for conservation efforts if viable populations of these range-restricted endemics are to be successfully maintained in Wallacea.

\section{ACKNOWLEDGMENTS}

This study was conducted as part of the Lambusango Forest Research Project, supported by Operation Wallacea, sponsored by the Wallacea Foundation, Kementerian Negara Riset dan Teknologi (RISTEK) Indonesia and the Indonesian Institute of Science (LIPI). The authors would like to thank Dr Tim Coles, Dr Phillip Wheeler, Dr Martin Jones and the Operation Wallacea scientific and logistic teams, especially Mr Dani Heryadi and Mr Tasman, for their support in this project. The authors would also like to acknowledge the valuable assistance of the Operation Wallacea volunteers who assisted with data collection, most notably James Owen, Keely Craig, and Poi-San Looi, and of Simon Chew and Gemma Davies. Finally, the authors would like to express thanks to the residents of Labundo Bundo for their hospitality.

\section{REFERENCES}

Achard, F., H.D. Eva, H.J. Stibig, P. Mayaux, J. Gallego, T. Richards, and J.P. Malingreau. 2002. Determination of deforestation rates of the world's humid tropical forests. Science 297: 999-1002.

Anggraini, K., M. Kinnaird, and T. O'Brien. 2000. The effects of fruit availability and habitat disturbance on an assemblage of Sumatran hornbills. Bird Conservation International 10: 189-202.

Barlow, J., L.A.M. Mestre, T.A. Gardner, and C.A. Peres. 2007. The value of primary, secondary and plantation forests for Amazonian birds. Biological Conservation 136: 212-231.

Bibby, C.J., N.D. Burgess, D.A. Hill, and S.H. Mustoe. 2002. Bird Census Techniques Second edition. London: Academic Press.

BirdLife International. 2008. http://www.birdlife.org/datazone/index.html

BirdLife International. 2008. The Harapan rainforest initiative, Sumatra. Cambridge/Jakarta: BirdLife International.

BirdLife International. 2004. Threatened birds of the world. 2004. Cambridge: BirdLife International.

Boyer, A.G. 2008. Extinction patterns in the avifauna of the Hawaiian islands. Diversity and Distributions 14: 509-517.

Brown, N., S. Jennings, P. Wheeler, and J. Nabe-Nielsen. 2000. An improved method for the rapid assessment of forest understorey light environments. Journal of Applied Ecology 37: 1044-1053.

Burgess, N., N. Doggart, and J.C. Lovett. 2002. The Ulguru mountains of Eastern Tanzania: the effect of forest loss on biodiversity. Oryx 36: $140-152$.

Cahill, A.J. 2003. Nest characteristics of the Red-knobbed Hornbill Aceros cassidix and Sulawesi Dwarf Hornbill Penelopides exhartus. Ibis 145: 97-113.

Canaday, C. 1996. Loss of insectivorous birds along a gradient of human impact in Amazonia. Biological Conservation 136: 212-231.

Cannon, C.H., M. Summers, J.R. Harting, and P.J.A. Kessler. 2007. Developing conservation priorities based on forest type, condition, and threats in a poorly known ecoregion: Sulawesi, Indonesia. Biotropica 39: 747-759.

Caro, T.M. and G. O' Doherty. 1999. On the use of surrogate species in conservation biology. Conservation Biology 13: 805-814.

Catterall, M. 1997. Bird survey of Buton Island 1996-1997. Operation Wallacea report.

Clements, J. F. 2007. The Clements checklist of the birds of the world. New York: Cornell University Press.

Coates, B.J. and K.D. Bishop. 1997. A guide to the birds of Wallacea. Alderley: Dove publications.

Colwell, R.K. 2006. EstimateS: Statistical Estimation of Species Richness and Shared Species from Samples, Version 8.0.0. User's guide and application. Available from: $<$ http//viceroy.eeb.uconn.edu/estimates $>$.

Colwell, R.K. and J.A. Coddington. 1994. Estimating terrestrial biodiversity through extrapolation. Philosophical Transactions of the Royal Society 
of London B 345: 101-118.

Connell, J.H. (1978) Diversity in tropical rainforests and coral reefs. Science 199: $1302-1310$

Fermon, H., M. Waltert, R.I. Vane-Wright, and M. Muhlenberg. 2005. Forest use and vertical stratification in fruit-feeding butterflies of Sulawesi, Indonesia: impacts for conservation. Biodiversity and Conservation 14: $333-350$.

Fjeldsa, J. 1999. The impact of human forest disturbance on the endemic avifauna of the Udzungwa mountains, Tanzania. Bird Conservation International 9: 47-62.

Forest Watch Indonesia/Global Forest Watch (2002) The state of the forest: Indonesia. Indonesia: Forest Watch and Washington DC: Forest Watch.

Gaston, K.J. and T.M. Blackburn. 1995. Birds, body size and the threat of extinction. Philosophical Transactions: Biological Sciences 347: $205-212$.

Gillespie, G.R., S. Howard, D. Lockie, M. Scroggie, and Boeadi. 2005. Herpetofaunal richness and community structure of offshore islands of Sulawesi, Indonesia. Biotropica 37: 279-290.

Gray, M.A., S.L. Baldauf, P.J. Mayhew and J.K. Hill. 2009. The response of avian feeding guilds to tropical forest disturbance. Conservation Biology 21: 133-141.

Herzog, S.K., M. Kessler and T.M. Cahill. 2002. Estimating species richness of tropical bird communities from rapid assessment data. The Auk 119: 749-769.

International Union for Conservation of Nature and Natural Resources Red List. 2009. www.iucnredlist.org/

Johnson, T.H. and A.J. Stattersfield. 1990. A global review of island endemic birds. Ibis 132: 167-180.

Kessler, M., P.J.A. Kessler, S.R. Gradstein, K. Bach, M. Schmull and R. Pitopang. 2005. Tree diversity in primary forest and different land use systems in Central Sulawesi, Indonesia. Biodiversity and Conservation 14: $547-560$.

Kinnaird, M. 1998. Evidence for effective seed dispersal by the Sulawesi Knobbed Red-Hornbill, Aceros cassidix. Biotropica 30: 50-55.

Kinnaird, M. 1995. North Sulawesi: A natural history. Jakarta: Wallacea Development Institute.

Lee, D.C. and S.J. Marsden. 2008. Adjusting count period strategies to improve the accuracy of forest bird abundance estimates from point transect distance sampling surveys. Ibis 150: 315-325.

Lee, T.M., N.S. Sodhi and D.M. Prawiradilaga. 2007. The importance of protected areas for the forest and endemic avifauna of Sulawesi (Indonesia). Ecological Applications 17: 1727-1741.

Lynch, J.F. 2005. Effects of point-count duration, time of day, and aural stimuli on detectability of migratory and resident bird species in Quintana Roo, Mexico. In Monitoring bird populations by point-counts, C.J. Ralph, J.R. Sauer and S. Droege, eds. USDA forest service General Technical Report.

Macarthur, R.H. and E.O. Wilson. 1967. The theory of island biogeography. Princeton: Princeton University Press.

Marsden, S.J. and J.D. Pilgrim. 2003. Factors influencing the abundance of parrots and hornbills in pristine and disturbed forests on New Britain, PNG. Ibis 145: 45-53.

Marsden, S.J. 1999. Estimation of parrot and hornbill densities using point count distance sampling method. Ibis 141: 377-390.

Marsden, S.J. 1998. Changes in bird abundance following selective logging on Seram, Indonesia. Conservation Biology 12: 605-611.

Mayaux, P., P. Holmgren, F. Achard, H.J. Eva, H. Stibig and A. Branthomme. 2005. Tropical forest cover change in the 1990s and options for future monitoring. Philosophical Transactions of the Royal Society B: Biological Sciences 360: 373-384.

McCune, B. and J.B. Grace. 2002. Analysis of ecological communities. Gleneden Beach, Oregon: MjM Software Design.

Myers, N., R.A. Mittermeier, C.G. Mittermeier, G.A.B. da Fonseca and J.
Kent. 2000. Biodiversity hotspots for conservation priorities. Nature 403: 853-858.

O'Donovan, G. 2001. Report on the botanical and ecological status of the Kakenauwe and Lambusanga Nature reserves on Buton Island, Sulawesi. Operation Wallacea report.

Peh, K., J. Jong, N. Sodhi, S. Lim and C. Yan. 2005. Lowland rainforest avifauna and human disturbance: persistence of primary forest birds in selectively logged forests and mixed-rural habitats of Southern peninsular Malaysia. Biological Conservation 123: 480-505.

Pimm, S.L., G.J. Russell, J.L. Gittleman and T.M. Brooks. 1995. The future of biodiversity. Science 296: 347-350.

Posa, M.R.C. and N.S. Sodhi. 2006. Effects of anthropogenic land use on forest birds and butterflies in Subic Bay, Philippines. Biological Conservation 129: 256-270.

Poulsen, B.O. and N. Krabbe. 1998. Avifaunal diversity of five high-altitude cloud forests on the Andean Western slope of Ecuador: testing a rapid assessment method. Journal of Biogeography 25: 83-93.

Primack, R. 1993. Essentials of conservation biology. Sunderland: Sinauer.

Pullin, A. 2002. Conservation biology. Cambridge: Cambridge University Press.

Seymour, A. 2004. Monitoring forest degradation and animal populations in the forests of central Buton: preliminary results from the pilot study. Operation Wallacea report.

Shankar-Raman, T.R. and R. Sukumar. 2002. Responses of tropical rainforest birds to abandoned plantations, edges and logged forest in the Western Ghats, India. Animal Conservation 5: 201-216.

Singer, H.A. and E. Purwanto. 2006. Misteri kekayaan hayati hutan Lambusango. Program konservasi hutan Lambusango (PKHL). Bau Bau: Operation Wallacea Trust.

Sodhi, N.S., L.P. Koh, D.M. Prawiradilaga, I. Tinulele, D.D. Putra and T. Han Tan Tong. 2005a. Land use and conservation value for forest birds in central Sulawesi. Biological Conservation 122: 547-558.

Sodhi, N.S., M.C.K. Soh, D.M. Prawiradilaga and B.W. Brook. 2005b. Persistence of rainforest birds in a recently logged area of central Java. Bird Conservation International 15: 173-191.

Sodhi, N.S., L.P. Koh, B. Brook, and P.K.L. Ng. 2004a. Southeast Asian biodiversity: an impending disaster. Trends in Ecology and Evolution 19: $654-660$

Sodhi, N.S., L.H. Liow and F.A. Bazzaz. 2004. Avian extinctions from tropical and sub-tropical forests. Annual review of Ecology, Evolution and Systematics 35: 325-345.

Stattersfield, A.J., M.J. Crosby, A.J. Long and D.C. Wege. 1998. Endemic Bird Areas of the World: Priorities for Biodiversity Conservation. Cambridge: Birdlife International.

Sutherland, W. 2000. The Conservation Handbook. Research, Management and Policy. London: Blackwell Science.

Thiollay, J.M. and Rahman, Z. 2002. The raptor community of central Sulawesi: habitat selection and conservation. Biological Conservation 107: 111-122.

Thiollay, J.M. 1997. Disturbance, selective logging and bird diversity: a Neotropical forest study. Biodiversity and Conservation 6: 1155-1173.

Trainor, C.R. 2007. Changes in bird species compositions on a remote and wellforested Wallacean island, South East Asia. Biological Conservation 140: 373-385.

Trevino, H.S., A.L. Skibiel, T.J. Karels and K.F. Dobson. 2007. Threats to avifauna on oceanic islands. Conservation Biology 21: 125-132.

Veddeler, D., C.H. Schulze, I. Steffan-Dewenter, D. Buchori and T. Tscharntke. 2005. The contribution of tropical secondary forest fragments to the conservation of fruit-feeding butterflies: effection of isolation and age. Biodiversity and Conservation 14: 3577-3592.

Waide, R.B. and J.M. Wunderle. 1987. Changes in habitats available to migrant land birds. Unpublished interim report submitted to World Wildlife Fund. 
Waltert, M., A. Mardiastuti, and M. Muhlenberg. 2005. Effects of deforestation and forest modification on understorey birds in central Sulawesi, Indonesia. Bird Conservation International 15: 257-273.

Waltert, M., A. Mardiastuti, and M. Muhlenberg. 2004. Effects of land use on bird species richness in Sulawesi, Indonesia. Conservation Biology 18: 1339-1346.

Walther, B. A. and S. Moran. 1998. Comparative performance of species richness estimation methods. Parasitology 116: 395-405.

Wells, M.G. 1998. World bird species checklist: With alternative English and scientific names. Bushey: Worldlist.

White, C.M.N. and M.D. Bruce. 1986. The birds of Wallacea (Sulawesi,
The Moluccas \& Lesser Sunda Islands, Indonesia. London: British Ornithologists Union.

Whitten, T., M. Mustafa, and G.S. Henderson. 2002. The ecology of Sulawesi. Singapore: Periplus Press.

Wilson, W.L. and A.D. Johns. 1982. Diversity and abundance in selected animal species in undisturbed forest, selectively logged forest and plantations in East Kalimantan, Indonesia. Biological Conservation 24: 205-218.

Wunderle, J.M. 1994. Census methods for Caribbean land birds. United States Department of Agriculture, New Orleans.

Zar, J.H. 1999. Biostatistical Analysis, 4th ed. Englewood Cliffs, NJ: PrenticeHall. 